\title{
Does Global English Support the Development of Social Europe?
}

\author{
László MARÁCZ \\ Institute for European Studies, University of Amsterdam \\ L.K.Maracz@uva.nl
}

\begin{abstract}
The relevance of languages and multilingual communication for social policy and solidarity in the context of the nation-state has generally been recognized. However, in the context of Europeanization, this factor has been underestimated and neglected in scientific research. This paper argues that languages and multilingual communication are relevant for the design of Social Europe. In order to support this hypothesis, the paper relies on an analytical tool, the so-called floral figuration model proposed by De Swaan (1988). This model allows us to isolate social and linguistic actors and track down complex patterns of linguistic and communicative exclusion in Europe's system of multilevel governance. These patterns also refer to international or global English or its technically adapted Brussels variety, 'Euro-English'. From this, also follows that these patterns of linguistic and communicative exclusion must be rendered into inclusive ones before a European social policy can be realized.
\end{abstract}

Keywords: European languages and multilingual communication, Social Europe, floral figuration model, Eurostars, national cosmopolitans

\section{Introduction}

Commentators recognize that there is a close relation between politics, language, and solidarity at the level of national political cultures. According to Rothstein (1998), although not being completely convinced of the role political cultures play concerning solidarity, social protection is conditioned by the perception of reciprocity. Reciprocity is, however, guaranteed best in a system of bounding and bonding, as it is outlined in Ferrera (2005). According to Ferrera, social protection has always been dependent on two social mechanisms: first, the bounding of a territory, nation-state borders and, second, bonding, the creation of a bond of solidarity or sharing within the boundaries of the national community, which may temporarily include foreigners and relies on factors, such as territory, nationality, residence, language, citizenship, and a sense of belonging to community. Note that 
among the factors inducing solidarity Ferrera refers to language as well. Although this position considers the relation between politics and language to be relevant for solidarity at the national level, this relation is seriously underestimated and neglected in research in the context of Europeanization.

Even Philippe van Parijs, the advocate of turning international English into a global lingua franca in order to overcome the communication problem in Europe and the world, posing the basis for more justice in the world - and he honestly includes social justice -, admits that a common language is a prerequisite for forming a demos, i.e. a nation-state in the sense of Ferrera. Hence, this demos is an important precondition for economic solidarity at a local level (Van Parijs 2011: 195). However, solidarity, even within the context of the nation-state including a demos based on a common language, remains a difficult matter, as Jeene et al. (2013) point out. If common language is a building block for solidarity, it is hard to imagine how a social policy at the European level could be realized when a common language or communication patterns including the European citizen are absent. For now, this is the present state of affairs since linguistic diversity is considered as a cornerstone of European identity.

This paper will investigate the relation between languages, multilingual communication, and social policy in Europe; more precisely, it offers an analysis of the present state of affairs that is the result of the interplay of Europe's system of multilevel governance and its multilingual identity. This interplay is captured in De Swaan's (1988) floral figuration model, which is an analytical tool to isolate the linguistic groups and actors in the European Union and their mutual interaction on the different levels of governance, namely the EU, national and local levels. The model also gives insight into the position of international English which is functioning more and more as a lingua franca in the European institutions in Brussels. Below we will demonstrate that the floral figuration model makes patterns of exclusion of linguistic actors visible. Hence, such patterns seriously hamper the design of a social policy for Europe. We will conclude, however, that languages, lingua franca, and multilingual communication will be relevant for the realization of Social Europe. Let us first consider the floral figuration model in more detail.

\section{The Floral Figuration Model}

The starting point of an analysis of European multilingualism and multilingual communication is the concept of multilevel governance within the European Union, normally described as a tripartite system consisting of different levels of governance, including the supranational EU-level, the national level of the Member States, and the local or regional level of government and policy-making 
(Hooghe-Marks 2002, McCormick 2015). The question is how multilingualism and multilingual communication in Europe fit into the system of multilevel governance. For this purpose, I will adopt the floral figuration model for languages, which has been proposed by De Swaan (1988). This model depicts the language competence of social groups and their hierarchical orderings in terms of power (Bourdieu, 1991). Although De Swaan introduced the floral figuration model to track down the socio-political implications of linguistic relations at the national level, it is my conviction that his model can be used as a fruitful analytical frame for European Union purposes as well.

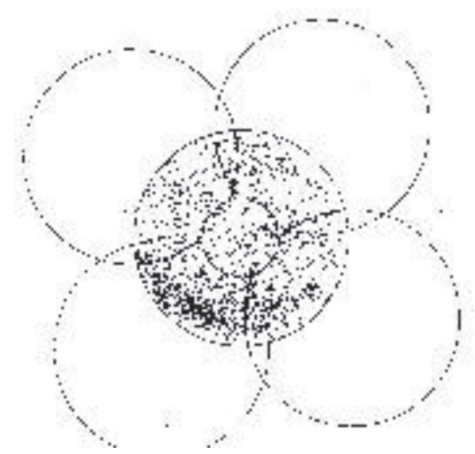

Figure 1. The floral figuration for linguistic actors in the European Union

This figure depicts the language situation in the European Union. In the outer circles, the European masses, the commoners in Europe's Member States are located. The commoners speak a national or regional language as their mother tongue, they have received some sort of basic (elementary and secondary) education in their mother tongue and might speak a European language of wider communication such as English, Spanish, French, or German. If they do speak a language of wider communication, it is not the standardized variety of these languages. Rather it will be an 'anything goes' variety. The shaded area represents speakers who belong to the European plurilingual elites, who have a much better control of their mother tongue and the European languages of wider communication than the commoners. Fligstein (2010: 156) refers to them as '... the educated, owners of business, managers, and professionals, and the young.' These groups form in fact a 'class' and participate in transnational networks within Europe. Those in the core star are the European cosmopolitan elites, the Eurostars, as Favell $(2008: 144,145)$ calls them. They use English as the European communication language. Kuus (2014: 56), who interviewed a number of European diplomats in the European External Action Service, describes this operating language as 'a technical language of eurospeak'. Note further that in the floral figuration model local speech communities are hardly intersecting with each 
other, but all of them are linked to plurilingual local elites through the mediation of one central or national language. These local, regional, or national elites - I will refer to them as national cosmopolitans - are acting as interfaces between the commoners, who have basically monolingual language and communication skills, and the plurilingual Eurostars. 'Plurilingual' means, apart from the native tongue, first and foremost 'this technical language of eurosprak', which is based on English and functioning as a lingua franca. This adapted version of English in the Brussels institutions is sometimes also referred to as Euro-English. Hence, the shaded area is communicating via Euro-English at the expense of the other official European languages, including standard British English. My analysis in terms of this model is to be considered as a first approximation of the various interests that determine the sociological aspects of European linguistic diversity.

\section{Languages and Multilingual Communication in Europe}

From its founding treaty in 1958, Europe has stipulated that all the languages of the Member States are official languages. Language regulation 1/1958 turned four languages - official and regional languages in France, Germany, Italy, and the Benelux countries - into official European languages (Labrie 1994). These four languages, including French, German, Italian, and Dutch, enjoyed an equal status in the institutions of the European Common Market, implying that they were to be used as institutional and working languages. With every new round of expansion, new Member States had the right to propose new official languages. The language regulation remained operative and, as a consequence, all official languages of new Member States were recognized as official European languages. At present, the EU recognizes 24 official languages. Linguistic diversity in Brussels is hard to manage, however. Hence, the distinction between 'official' versus 'working' language has become relevant, and this is practically used as a solution for the language issue in the Brussels institutions. The difference between official and working languages is defined in Article 6 of the language regulation: the institutions are allowed to freely choose their own language regime. The European Commission acknowledges three working languages, namely English, which is used the most, French, and German. The latter is used substantially less than the other two languages (Marácz-Rosello 2012). Another example of Article 6 is the fact that out of the fifteen Directorate Generals (DGs) only three use the 24 official languages on their website, including Employment, Social Affairs, and Inclusion (EMPL), Enterprise and Industry (ENTR), and Justice (Just) (Gazzola 2014). All other DGs use a reduced or a monolingual regime consisting of English-only. 
It is clear that English is on the rise as a global lingua franca (Phillipson 2006, 2009, De Swaan 2001, Van Parijs 2011, Haselhuber 2012, Grin 2014, and Ricento 2015). It is convincingly argued that the expansion of English on a global scale is driven by the hegemonic political and economic positions established first by the British Empire and later on in the twentieth century by the United States. The situation of global English is for a number of reasons not unproblematic, though. Firstly, the conclusion is justified that English is associated with linguistic hegemony and domination at the expense of other languages. Secondly, English cannot function as a real lingua franca, that is as a neutral mediator language respecting the linguistic background of all speakers involved in communicative events due to the fact that English is spoken by native and non-native speakers alike. Thirdly, there are different versions of English in use, such as British English, American English, and so on, which makes it for the foreign speakers of English difficult to know what the precise norms of English are, although there exists the regularly accepted normative variety of English, standard British English, which is spread by important language mediators, such as BBC radio and television, and is taught to foreign speakers of English in formal education. So, the variety of global English functioning as a bridge language among nonnatives should be English-as-a-foreign language in fact. However, it has been observed that this normative variety of English is not spoken across the globe, but rather a basic version of English mixing, intermingling, and sampling with local languages as an outcome of language use and communication (Edwards 2012: 34-38, Hülmbauer-Böhringer-Seidlhofer 2008).

Let us recall that Figure 1 depicts linguistic diversity in terms of a demarcation between European elites and commoners. The European elites, i.e. the Eurostars and the national cosmopolitans, although positioned in different geographical spaces, i.e. the Brussels centre and the Member States, are positioned in a common virtual space. They form a connected transnational class and speak the same sort of fluid language for instrumental communicative purposes only, i.e. a European variety of international English, i.e. Euro-English. Euro-English is developing its own characteristics, such as misused English words and expressions (European Court of Auditors 2013), and has adopted artificial expressions, e.g. from the financial world, like 'collateralized debt obligations', 'asset-backed securities', and 'credit default swaps' (Maier, 2014: 210). This is 'de-contextualized English' pinned down in Barbier (2014) or 'the technical language of eurospeak' referred to in Kuus (2014). It is hard to imagine that this variety of English will be able to mediate between the different political cultures in Europe that are rooted in language, as Ferrera (2005) and Barbier (2013, 2014) argue for. However, whatever its status or quality according to the last dataset of Eurobarometer (see Eurobarometer 386), roughly 50 percent of the EU citizens do not have any knowledge of English at all. So, a restricted linguistic regime with English or 
consisting of English-only would privilege the higher educated, the better-off in Europe, seriously undermining Social Europe (Gazzola 2014).

\section{Concluding Remarks}

So far, Europeanization has been a project that has served the interests of the European elites, i.e. of those that can make optimal use of the European freedoms, mobility, and markets. In the framework of the floral figuration model, I referred to the European elites as Eurostars and national cosmopolitans. However, the challenge is to keep Europe attractive not only for its elites but also for its commoners. Wallace et al. (2015) observe that social policy within the EU is still a matter of the Member States. Hence, the task is to develop a genuine Social Europe that offers solidarity for all of its citizens. Although the diverging interests between the European elites and commoners has been noticed in the literature such as in Fligstein's ‘Euro-clash' (Fligstein 2008), it has gone unnoticed that the Euro-clash between social groups involves unbridgeable language conflicts as well.

In this paper, I have argued that language issues are vital for the development of Social Europe. Although the importance of language and communication is recognized at the state level, this topic is quite often neglected when it comes to the European level. The interplay between multilevel and linguistic governance in Europe can best be analysed in terms of the floral figuration model in the sense of De Swaan (1988). The typology of social actors, their language skills, their communication channels and styles, and their positioning in this model demonstrate that in the present constellation transparent, efficient, and fair communication is impossible. The multilingual communication patterns are first and foremost group-specific and exclusivist. The introduction of an Englishbased lingua franca in Europe, a sort of Euro-English, will not be sufficient to solve the linguistic and communicative deficits. Hence, the absence of a neutral, transparent, and accessible lingua franca jeopardizes the development of Social Europe.

The author is indebted to Jean-Claude Barbier for inspiring discussions on Social Europe. The research leading to these results has received funding from the European Union's Seventh Framework Programme (FP7/2007-2013) under Grant Agreement No 613344. 


\section{References}

BARBIER, J.-C. 2013. The Road to Social Europe: a Contemporary Approach to Political Cultures and Diversity in Europe. London-New York: Routledge. 2014. The Myth of English Language Competence in Europe and Some of Its Consequences. Paper presented at the Symposium Economics, Linguistic Justice and Language Policy. Humboldt-Universität zu Berlin, 2-3 March 2015. BOURDIEU, P. 1991 Language and Symbolic Power. Cambridge: Polity Press.

DE SWAAN, A. 1988. Care of the State: Health Care, Education and Welfare in Europe and the USA in the Modern Era. New York: Oxford University Press. EDWARDS, J. 2012. Multilingualism. Understanding Linguistic Diversity. London: Continuum.

FAVELL, A. 2008. Eurostars and Eurocities: Free Movement and Mobility in an Integrating Europe. Oxford: Blackwell Publishing.

FERRERA, M. 2005. The Boundaries of Welfare, European Integration and the New Spatial Politics of Social Protection. Oxford: Oxford University Press.

FLIGSTEIN, N. 2008. Euro-clash, the EU, European Identity and the Future of Europe. Oxford: Oxford University Press.

GAZZOLA, M. 2014. Multilingualism for Effective Communication. An Evaluation of the European Commission's de facto Language Policy. Paper presented at the conference Multidisciplinary Approaches in Language Policy and Planning, 4-6 September, 2014, University of Calgary.

GRIN, F. 2014. Fashionable Sociolinguistic Constructs: Some Implications for Politics and Policy. Paper presented at the RECODE Workshop The Politics of Multilingualism: Linguistic Governance, Globalisation and Europeanization, 19-20 June, 2014, University of Geneva.

HASELHUBER, J. 2012. Mehrsprachigkeit in der Europäischen Union: eine Analyse der EU-Sprachenpolitik, mit besonderem Fokus auf Deutschland. Frankfurt am Main: Peter Lang.

HOOGHE, L.-MARKS, G. 2001. Multi-level Governance and European Integration.

Oxford: Rowman and Littlefield.

HÜLMBAUER, C.-BÖHRINGER, H.-SEIDLHOFER, B. 2008. Introducing English as a Lingua Franca (ELF): Precursor and Partner in Intercultural Communication. Synergies Europe 3: 25-36.

JEENE, M.-VAN OORSCHOT, W.-UUNK, W. 2013. The Dynamics of Welfare Opinions in Changing, Economic, Institutional and Political Contexts: An Empirical Analysis of Dutch Deservingness Opinions, 1975-2006. Social Indicators Research. DOI: 10.1007/s11205-012-0230-6.

KUUS, M. 2014. Geopolitics and Expertise. Knowledge and Authority in European Diplomacy. Oxford: Wiley Blackwell. 
LABRIE, N. 1994. La construction linguistique de la communauté européenne. Paris: Champion.

Maier, M. 2014. Die Plünderung der Welt, Wie die Finanz-Eliten unsere Enteignung planen. Spiegel bestseller.

MARÁCZ, L.-ROSELLO, M. (eds). 2012. Multilingual Europe, Multilingual Europeans. Amsterdam-New York: Rodopi.

MCCORMICK, J. 2015. European Union Politics. Second edition. Basingstoke: Palgrave MacMillan.

PHILLIPSON, R. 2006. English-Only Europe? Challenging Language Policy. London: Routledge. 2009. Linguistic Imperialism Continued. New York: Routledge.

RICENTO, T. (ed.). 2015. Language Policy and Political Economy: English in a Global Context. Oxford: Oxford University Press.

ROTHSTEIN, B. 1998. Just Institutions Matter, the Moral and Political Logic of the Universal Welfare State. Cambridge: Cambridge University Press.

SCHARPF, F. 2010. The Asymmetry of European Integration, or Why the EU Cannot Be a Social Market Economy. Socio-Economic Review 8(2): 211-250.

VAN MEURS, W. et al. 2013. Europa in alle staten. Zestig jaar geschiedenis van de Europese integratie. Nijmegen: Uitgeverij Vantilt.

VAN MIDDELAAR, L. 2013. The Passage to Europe: How a Continent Became a Union. Yale University Press.

VAN PARIJS, P. 2011. Linguistic Justice for Europe and for the World. Oxford: Oxford University Press.

WALLACE, H.-POLLACK, M.-YOUNG, A. 2015. Policy-Making in the European Union Oxford: Oxford University Press.

\section{Files}

European Commission, (June 2012), Special Eurobarometer 386, Europeans and Their Languages. European Court of Auditors, Secretariat General Translation Directorate, Misused English Words and Expressions in EU publications, September 2013, Brussels, http://ec.europa.eu/translation/english/guidelines/ documents/misused_english_terminology_eu_publications_en.pdf, accessed on: 18 February 2015. 